Abstract.The article discusses the social and economic prerequisites for the formation of a "biographical culture" in the United States during the XX - beginning XXI centuries. Under the term "biographical culture", the author understands the process of creating biographical narratives. Also, this term includes social-economic conditions in which biographical narratives influence the creation of the image of a certain personality in the collective consciousness.

Using the comparative method, the study analyzes the socio-economic systems of the two states, within which were formed various "biographical cultures". The article defines three criteria for the development of the state and society, which directly affect the creation of this culture. The first criterion is the presence or absence of a free market in the state. The second criterion is the existence of censorship in the state. The third criterion is the degree of development of the infrastructure for the distribution of biographical works and the level of its state's dependence.

The analysis based on the thesis that active and passive societies exist in different countries. Their development depends on the political, economic and ideological conditions. Based on the study, the author concluded that US society is classified as active. This means that it can produce and distribute biographical works independently without pressure from the state. Accordingly, the images of personalities created in biographical works in the USA reflect the preferences and value orientations of American society. Social values, which are reflected in the way of creating the image of a biography's hero, develop and transform organically, but not under the pressure of a state machine.

Keywords: biographicalworks, "biographicalculture", socio-economicconditions, USA, personality, socialvalues.

UDK 94:502.7(73)

http://doi.org/10.17721/2521-1706.2018.06.20-30

Tetiana Perga, Ph.D., Senior Researcher, State Institution "Institute of World History of NAS of Ukraine", Kyiv

\title{
THE VALUE OF WILDLIFE IN THE US: FROM THE IDEA TO PRACTICE
}

\begin{abstract}
The development of the idea of wildlife conservation in the USA has investigated. The role of colonization of the North American continent in attracting interest to wildife has identified. Two vector of such influence are determined: negative impact (destruction of many species of flora and fauna) and positive (the discovery of unique natural landscapes). The contribution of American painters, writers, scholars and statesmen of late 19th - 20th centuries in the disclosure of the non-economic value of wildlife and the creation of the first areas of its protection has defined. The US legislation on wildlife conservation in the twentieth century has analyzed. The role of US President Theodore Roosevelt in establishing the first US nature reserves has revealed. It has concluded that on the eve of the World War II, in American society has already spread an understanding of the importance of protecting wildlife and American presidents carried out fragmentary measures in this area. Despite the widespread perception of wildlife in American society in terms of assessing its economic value, which was associated with the needs of hunting and tourism development, an understanding of the importance of preserving the species of wild flora and fauna for the development of ecosystems has been already developed. On this basis, in the second half of the twentieth century the first legislative acts on the protection of wildlife were adopted. It has proved that the first in the world the United States gave a legal definition of wildlife and enshrined it in the 1964 the Wilderness Act. The term "wild river" introduced by the Wild and Scenic Rivers Act (1968) has analyzed. The growth of the
\end{abstract}


National System of Wildlife Refuges and the procedure for the creation of such sites in the USA has considered. The modern problems of wildlife conservation in the USA are clarified. It is found that they are closely connected with the considerable increase of resource requirements due to population growth and urbanization. A conclusion is made about the US influence on the development of wildlife conservation in European countries, which adopted the first laws in wildlife protection only in 1990s.

Key words: wildlife, USA, environmental protection, colonization.

Wild nature has attracted the attention of people from ancient times, although it caused both feelings of fear and adoration. Concept "wildlife" usually refers to areas that have not undergone any changes in the process of human activity, preserved many species of flora and fauna and natural landscapes. The tendency of recent decades is a gradual rethinking of its place in the human life. The idea that wildlife is something "completely different from the sphere of our reality, which belongs to a completely different area that excites a violent interest in the soul" is increasingly spread. An important role in the development of wildlife conservation policy has played the United States of America. In this country the first in the world was drown attention to the value of wildlife which provided the basis for the establishment of the environmental movement and state policy.

The purpose of the article is to analyze the development of the wildlife conservation idea in the United States and its implementation in the state environmental policy. This has considerable practical interest for Ukraine, which in recent years began to develop activities in this field.

\section{Development of wildlife theory in Ukrainian and foreign science}

In the Ukrainian scientific terminology, the term "wildlife" is absent. This shows that this scientific problem has not been developed on the theoretical level as well as in the practice. Therefore Ukrainian historiography on the issues of the wildlife conservation is limited. It is necessary to highlight a series of works by $\mathrm{V}$. Boreyko on ecological ethics, philosophical principles of wildlife conservation, preservation of virgin forests in Ukraine [3]. There is also a group of works (V. Andronov, E. Varyvoda, G. Titenko, etc.), in which wildlife is investigated in the context of conservation policy in Ukraine [1]. They are oriented primarily on the analysis of the establishment the protected territories in Ukraine.

Modern foreign studies on this issue has an interdisciplinary character and views wildlife through the prism of essays on environmental degradation, tragedies of communities, chronicles of scientific discoveries, scientific discussions about destruction of values, reorganization of spatial relations, environmental policy and social justice. In addition, many works devoted to the practical aspects of protecting nature.

The most notable contribution to the development of wildlife conservation idea in the USA made thinkers and public figures of the nineteenth century, such as R. Emerson, J. Marsh, G. Toro, J. Muir. In American science, in the works of H. Rolston III, J. Turner, R. Nash, etc. there is an opinion that their romantic assessment of wildlife in the nineteenth century has initiated a new approach to nature in general, which significantly differed to antipathies which people have long felt to the unknown spaces. For example, R. Nash believes that wildlife began as an unrecognized and unnamed ecological norm for many years of Earth's history, and was formed as a concept of civilization, after which it was a subject of hatred and fear for a long time, and more than recently began to be appreciated [8]. This argues the conclusion about the primacy of the United States in the development of the concept of wildlife and the idea of its protection. 


\section{The development of wildlife protection idea}

If to compare the US with the countries of the European continent, one can state the objective character of this thesis. For many centuries on the North American continent was indifference and hostile attitude to nature. Everything that was unknown frightened, developing an idea of wild space, as a damned and wicked place. Colonization of the territories caused dislike of wildlife due to the difficulties and dangers which encountered pioneers. In addition, the development of new lands was accompanied by the destruction of many species of flora and fauna and the change of the natural landscape due to the development of farms, grazing livestock, the construction of cities and railways, hunting. For example, in the 1870's, the buffalo population disappeared almost completely in the United States (in 1886, left only 540 animals) [4]. Buffalo were killed only for the sake of the skin, leaving the carcass rotting in the woods. The same fate encountered many other species of flora and fauna. Meat of ducks, swans, and geese considered a delicacy not only in America, but also in Russia and many European countries. In addition, due to the fashion to decorate of women's hats with feathers in late nineteenth - early twentieth century many species of wild birds (hummingbird, white cranes, pink and ibis and parrots, purple cardinals, American thrushes) were under the threat of disappearing. In 1914, in the zoo of Cincinnati, died the last postal pigeon in the United States [6].

However, colonization had also positive effects for nature. Over the past decades, the themes of cultural collision, colonization, the American frontier are becoming more and more popular. Many American researchers believe that the establishment of borders in the late twenty-first century contributed to the Americans' understanding of the uniqueness of their nature, which influenced the formation of national identity. This idea can be illustrated in the example of R. Nash's work "Wilderness and the American mind." The researcher claims that at first, Americans viewed forests and fields intact as empty lands. But by the middle of the XIX century, a small group of artists and writers began to look at an underdeveloped countryside as a place of romantic escape from civilization and a subject of national pride, a feature that distinguished the United States from Europe. The emergence of cities as a result of industrial development and the "closure" of the border encouraged a new assessment of the primary landscape [8].

Undoubtedly, the greatest merit of American artists is the transformation of the original American landscape into a national symbol of the United States. Under the influence of romanticism in the 1830's, a national school of wildlife artists, called the Hudson River School, formed in the country. The artists of this school glorified the wildlife of America (first of all - the American desert, the valley of the Hudson River and its environs, mountains in northeastern New York state - Adirondack, a physiographic province of the larger Appalachian Mountains - the Catskill Mountains, the White Mountains of New Hampshire) and tried to show that their holiness and virginity wildlife remains a standard of innocence and purity. The same position is also observed in the works of R. Emerson, J. Marsh, G. Toro, J. Muir, who allowed to look at the wild nature, which at that time considered to be something unnecessary, bad and unworthy, both moral and free, the source of holiness and inspiration, for which it needs to be appreciated. They accessed its non-economic, aesthetic value and equated it with human rights $[9$, p. 83].

The peculiarity of the situation in the US is the emergence not only of scientists, but also of hunters a sense of deep concern about the decline in game species. This led to the foundation in 1870s-1890's a number of societies and initiatives that promoted the idea of a thriving relation to plants, animals and birds (New York Botanical Club, Ornithological 
Club of Cambridge, American Ornithological Association, Naturalists' Association of the Eastern States, the Sierra club, later - the environmental society "Audubon") [10, p. 18].

From the first days, nature conservation in the United States became the scene for the struggle of two groups of people - conservationists - people who advocated for the rational exploitation of natural resources and preservationists, whose followers supported the idea of the inviolability of wildlife. However, the existing economic paradigm contributed to the development of utilitarian approach to the environment, and the US political elite had chosen conservation as a model of environmental protection policy. This put on the first place the economic value of nature. Conservation illustrated the idea of "wise" use of resources in order to ensure the country's economic growth in the interests of present and future generations. However, the idea of protecting wildlife, in particular of endangered species of flora and fauna, has already rooted in the minds of many representatives of American society.

\section{Implementation of wildlife protection \\ in the first half of the twentieth century}

In the activities of the 26th president of the United States one can find the first attempt to realize the idea of wildlife conservation. During two presidency cadencies, he created the United States Forest Service, 150 national forests, 51 federal bird reserves, 4 national game preserves, 5 national parks, and 18 national monuments; 230 million acres of land have received the status of protected by the state areas. On March 14, 1903, the US's first National Wildlife Refuge in the Pelican Island National Reserve was created [7; $11]$.

At the beginning of the twentieth century, the first attempts have been made to restrict hunting in the United States, which was one of the main reasons for the reduction of the populations of some animals and birds. In 1918, the Migratory Bird Treaty Act came into force. It approved the powers of the federal government to establish seasons and limits of hunting [21]. In 1934, Congress adopted the Migratory Bird Hunting and Conservation Stamp Act [20] which providing a source of funding for the acquisition and management of waterfowl habitat. It served not only as a stamp for collecting, but also as a ticket for the entrance to the national wildlife refuges. The stamp is valid until today; the income from its sale transfers for the conservation of wetlands $(98 \%$ of income is sending to the Migratory Bird Conservation Fund). Since the introduction of the stamp, this fund has already received more than $\$ 1$ billion.

The first pilot project for the conservation of wildlife was implemented by American eco-philosopher, founder of the theory of environmental ethics O. Leopold. In 1924, he persuaded the U.S. Forest Service set aside 755,000 acres as the Gila Wilderness, the first "wilderness" designation in the world. In the same year, the Congress created Upper Mississippi River National Wildlife and Fish Refuge. Leopold was the first to start the using of the term "wildlife" to reflect his vision of preserving nature in the United States. In the 1930's he published a book on scientific management of such territories and became one of the country's leading experts in the wildlife issues. In his works O. Leopold substantiated the theory of environmental ethics, which he called the ethics of the Earth. His book "The Almanac of the Sandy County" (1949) gave impetus to the intellectual search in this area and the development of such direction of philosophy as ecosophia. In addition, O. Leopold was a member of the Wilderness Society created in 1935 [5].

In 1929, the Migratory Bird Conservation Act came into force. It authorized the purchase or lease of areas for waterfowl storage facilities. Its implementation demanded \$ 
7.9 million [13]. Migratory Bird Conservation Commission was also established to approve the territories recommended by the Secretary of the Interior for these needs. In 1931, it was supplemented by the Animal Disease Control Act, which gave the U.S. Department of Interior broad powers to control activities that inflict damage on predators, rodents and birds [19].

In the 1930's, despite the economic depression, wildlife conservation continued. In 1934, U.S. President F. Roosevelt appointed of J. Norwood, T. Beek and O. Leopold to serve on a Blue Ribbon committee. Its aim was to explore the needs of waterfowl. The Fish and Wildlife Coordination Act of 1934, authorizes the Secretaries of Agriculture and Commerce to provide assistance to and cooperate with Federal and State agencies to protect, rear, stock, and increase the supply of game and fur-bearing animals, as well as to study the effects of domestic sewage, trade wastes, and other polluting substances on wildlife [17].

In 1935, the Lacey Act prohibited foreign trade on illegally acquired wildlife species (Lacey Act, 1935). In 1937, the Congress adopted the Wildlife Restoration Act of 1937, which expanded the sources of funding the conservation and development of wildlife. It directed taxes on firearms and ammunition sales back to the individual states to fund wildlife management and habitat protection [27]. A number of anti-crisis programs within the framework of New Deal have led to the development of national parks, animal storage facilities, expansion of afforestation, and the fight against land erosion. In 1937, Bankhead-Jones Farm Tenant Act came into force and authorized federal government to acquire damaged lands to rehabilitate and use them for various purposes [14]. In 1940, the U.S. Fish and Wildlife Service was established. After the World War II, the principles of the institution' activities, based on the ethics of the Earth O. Leopold, were formed. They rely on love and respect for the Earth and an understanding that wildlife and the immortality of diverse wildlife are essential to the quality of life of American society.

The facts which we mentioned in the first part of the article, show that at the eve of the World War II, in American society has already spread an understanding of the importance of protecting wildlife. Some activities also carried out in this area. The economic value of wildlife considered in terms of meeting the needs of hunting and tourism, but has already developed an understanding of the importance of preserving the species of wild flora and fauna for the development of ecosystems. The aesthetic value of "wilderness" manifested in the perceiving them as places of isolation from urban life, inspiration and pride for their country.

\section{Development of wildlife protection policy}

in the second half of the twentieth century

Systematic work in this area started in the second half of the twentieth century. In 1949, the Sierra Club initiated the first national conference on wildlife, which began a broad interdisciplinary discourse on wildlife and ways of preserving the unique corners of nature. Not only ecologists, biologists, geographers, foresters, but also philosophers, artists, writers, politicians, photographers, lawyers, musicians, economists, ethnologists, theologians participated in discussions. This allowed developing a view on the wildlife based on the understanding that it is not only a resource for the human development and a component of environmental systems and genetic reserve for biodiversity conservation, but also is valuable in itself. By this was recognized the ethical and aesthetic value of wildlife, the right of wild species of flora and fauna to exist, the need for a human attitude 
to environment and started to develop such direction of philosophy as environmental ethics, which contributed to the spread of such perception of wildlife.

The development of this discourse has demonstrated the need for a comprehensive national policy on wildlife protection. It started with the adoption of a number of acts. The Fish and Wildlife Act of 1956 confirmed the position of Commissioner of Fish and Wildlife and a United States Fish and Wildlife Service in the Department of the Interior, and established a Bureau of Sport Fisheries and Wildlife and a Bureau of Commercial Fisheries. It establishes a comprehensive national fish, shellfish, and wildlife resources policy and supported the inherent right of every citizen of USA to fish for pleasure, enjoyment, and betterment and to maintain and increase public opportunities for recreational use of fish and wildlife resources [16]. In 1958, Congress passed an amendment to the Wild Duck Act of 1934, which initiated the Waterfowl Restoration Program. For its financing, as well as for the accelerating of wetland conservation, in 1961 the Congress adopted the Wetlands Loan Act [19]. However, the allocated funds were insufficient and these legislative acts did not bring the expected results. By the early 1960s a wave of green movement responded to the growing public concern with the impact of industrial society on the quality of environment. It was also inspired by the book of biologist of the U.S. Fish and Wildlife Service Rachel Carson "Silent Spring." She substantiated the destructive effects of pesticides on nature and the death of many species. The spring without bird's twitter and singing which the author described, has forced to think about this problem both ordinary citizens and policy-makes responsible for the future of the planet. In the 1960's, in the United States a number of basic legislation that regulated various aspects of environmental policy were adopted.

From the perspective of preserving unique species of flora and fauna, the most important is the Wilderness Act of 1964. The first in the world, it has given a legal definition of wildlife. The wildlife area is recognized in this law as "an area of undeveloped Federal land retaining its primeval character and influence, without permanent improvements or human habitation, which is protected and managed so as to preserve its natural conditions and which (1) generally appears to have been affected primarily by the forces of nature, with the imprint of man's work substantially unnoticeable; (2) has outstanding opportunities for solitude or a primitive and unconfined type of recreation; (3) has at least five thousand acres of land or is of sufficient size as to make practicable its preservation and use in an unimpaired condition; and (4) may also contain ecological, geological, or other features of scientific, educational, scenic, or historical value" [26].

Although the law did not establish a separate wildlife agency, it defined and protected "wild" territories within federal lands, regardless their jurisdiction. At the moment, they are managed by dual mandate. On the one hand, they are considered the areas where the immovable natural state is preserved, and on the other hand, they are used to satisfy the Americans (both the aesthetic and the recreational needs in the form of outdoor recreation and activities that do not harm nature). These provisions developed the National Wildlife Refuge System Administration Act of 1966, which provided guidelines and directives for administration and management of all areas in National Wildlife Refuge system including "wildlife refuges, areas for the protection and conservation of fish and wildlife that are threatened with extinction, wildlife ranges, game ranges, wildlife management areas, and waterfowl production areas" [22]. According to the current legislation, commercial activities, use of roads and motor vehicles, construction of buildings and structures are prohibited in these territories. However, on these 
territories has allowed "easy" recreation, including traveling, fishing, boating, observation of various animals and birds, hunting (albeit with large restrictions), photography. This approach has been introduced to promote outdoor recreation, historically considered one of the ways to support the physical and mental health of Americans, as well as attracting their attention to the natural wealth of the country, cultivating a sense of pride and patriotism.

In addition, the United States the first in the world introduced the concept of "wild river" which considered a river or part of it that is freely current, free from reservoirs, has no other access, except for pedestrian paths, with catchment areas or coastlines, which are, basically, unchanged and with unpolluted water. In accordance with the Wild and Scenic Rivers Act (1968) the construction of dams, gutters, power stations, power lines and other objects, as well as mining of minerals in the channels, on the banks or in a quarter of a mile from the shore, is prohibited on such rivers. Wild rivers can be visited only on foot, on a horse or boat. Wild, picturesque and recreational rivers should have outstanding aesthetic, recreational, geological, historical, cultural values and biodiversity [25]. In accordance with this low the National Wildlife and Riverside System was created. As of August 2018, it includes 12,754 miles of 209 rivers in 40 states (approximately $0.25 \%$ of all US rivers).

Endangered Species Act of 1973 extended the Government's attention to the issues of the creation of games for wild fauna [15]. At present, it is the most important in the field of protection of species which under the threat destruction. Under his auspices in the US, more than 25 shelters for such species were established.

In 1980, U.S. President Carter signed the Alaska National Interest Lands Conservation Act which expanded the National Park System by 53 million acres [12]. In 1995, was adopted The Lacey Act: America's Premier Weapon in the Fight Against Unlawful Wildlife Trafficking [18]. In 1997, the Congress passed the National Wildlife Refuge System Improvement Act, which strengthens the mission of the Refuge System, clarifies priority public uses, and requires comprehensive conservation plans for every refuge [23].

In 1999, U.S. President Bill Clinton adopted a number of bills increased the National Wildlife Conservation System (approximately to 100 million acres). Currently, it already includes land and water on national wildlife refuges for more than 700 species of birds, 220 species of mammals, 250 reptile and amphibian species, and more than 1,000 species of fish. Each year, about 47 million Americans visit them. In 2013, revenue from domestic tourism amounted to $\$ 2.4$ billion [2]. According to current practice, the assignment of river sections to the National Wildlife and Riverside System is the responsibility of the Congress or, under certain circumstances, the Secretary of the Interior. Allocation of wildlife areas is conducted only by the US Congress. An increase in the National System of Wildlife Conservation is taking place on the initiative of public services, which, together with public environmental organizations, submit relevant legislative proposals for approval by the US Congress. However, the undoubted achievement is not the size of the territories, but the results of this policy and the attitude of the population towards wildlife.

In recent years, some species which were under the threat of destruction, such as bison, gray wolves, bald eagles, falcons-sapsanas, American alligators and grizzly bears, reindeer, turkeys are reproduced as a result of this activity at very fast pace. In this regard, American society is concerned about the new problem - the death of animals due 
to unintentional collision with the places of residence and life of people. This is especially true for deer, who which often go to the roads.

Modern problems of wildlife conservation in the United States are associated with a significant increase in resource requirements as a result of population growth and urbanization. American researchers believe that forests and agricultural lands are increasingly turning into commercial use, reducing the area of wildlife habitat and fragmenting what has left. Climate change that breaks ecosystems, increases fires and natural disasters, the transmission of diseases from domestic and wildlife as a result of the growth of international tourism greatly worsen the situation. Also, American society is worried about the virtualization of the lives of young generation that spend less time outdoors and rarely visit nature reserves and national parks. Undoubtedly, the U.S. Fish and Wildlife Service, the National Park Service, the Forest Service and other wildlife institutions understand these issues. Therefore, they are constantly expanding educational, scientific and cultural programs, and various tourist products aimed at encouraging visits to national forests, parks and wildlife sites.

\section{Conclusion}

United States of America is a leader of wildlife conservation. Under the influence of the United States, at the beginning of the XXI century the concept of wildlife began to evolve in the European countries. The first law in this field was adopted by Finland in 1991, however systematic work on the level of the EU and other Member States started at the beginning of the twenty-first century. The experience of the USA is actual and useful for Ukraine which only begin to build national policy in this field. The urgent task which can be the topic for the further research is the development the concept of wildlife protection in Ukraine.

\section{Список використаних джерел і літератури:}

1. Андронов В.А., Варивода Є.О., Тітенко Г.В. Заповідна справа: навч. посіб. / В.А. Андронов, Є.О. Варивода, Г.В. Титенко. - Харків: НУЦЗУ, 2013. - 204 с.

2. Annual Performance Report FY2015 [Електронний ресурс]. - Режим доступа: https://www.fws.gov/refuges/about/RefugeReports/pdfs/RAPP_Rpt_2015_final.pdf （Дата звернення 28.08.2019). - Назва з екрану.

3. Борейко В.Е. Охрана дикой природы в Украине и мире / В. Е. Борейко. - Київ: Логос, 2018. - 80 c.

4. Brown, R.D. The History of Wildlife Conservation and Research in the United States - and Implications for the Future [Електронний ресурс]. - Режим доступа:

http://http://citeseerx.ist.psu.edu/viewdoc/download?doi=10.1.1.494.2051\&rep=rep1\&type=pdf (Дата звернення: 17.08.2019). - Назва з екрану.

5. Curt, D.M., Berry W. Aldo Leopold: His Life and Work / D.M. Curt, W. Berry. - Wisconsin: University of Wisconsin Press, 2010. -655 p.

6. Дуглас У. О Трехсотлетняя война. Хроника экологического бедствия / У.О. Дугдас. Москва: Прогресс, 1975. - 240 c.

7. Lands Established by Theodore Roosevelt [Електронний ресурс]. - Режим доступа: http://https://www.nps.gov/thro/learn/historyculture/theodore-roosevelt-and-conservation.htm

(Дата звернення: 27.08.2019). - Назва з екрану.

8. Nash R. F. Wilderness and the American Mind / R.F. Nash. - New Haven: Yale University Press, 2001. -426 p.

9. Перга Т.Ю. Політика Теодора Рузвельта у сфері екології: консервація природних ресурсів / Т.Ю. Перга // Проблеми всесвітньої історії. - 2016. - №2. - С. 82-96.

10. Parkins A.E., Whitaker J.R. Our Natural Resources and Their Conservation / A.E. Parkins, J.R. Whitaker. - New York: John Wiley \& Sons, 1946. - 647 p. 
11. 11. Pelican Island [Електронний pecypc]. - Режим доступа: https://www.fws.gov/refuge/pelican_island/about/history.html (Дата звернення: 18.08.2019). - Назва 3 екрану.

12. 12.The Alaska National Interest Lands Conservation Act [Електронний ресурс]. - Режим доступа: https://www.nps.gov/locations/alaska/anilca.htm (Дата звернення: 19.08.2019). - Назва 3 екрану.

13. The Animal Disease Control Act [Електронний ресурс]. - Режим доступа:

https://www.congress.gov/107/plaws/pub19/PLAW-107pub19.pdf (Дата

звернення:

17.08.2019). - Назва з екрану.

14. The Bankhead-Jones Farm Tenant Act of 1937 [Електронний ресурс]. - Режим доступа: https://www.revolvy.com/page/Bankhead\%E2\%80\%93Jones-Farm-Tenant-Act-of-1937

звернення: 20.08.2019). - Назва з екрану.

15. The Endangered Species Act of 1973 [Електронний ресурс]. - Режим доступа:

https://www.fws.gov/laws/lawsdigest/esact.html (Дата звернення: 17.08.2019). - Назва 3 екрану.

16. The Fish and Wildlife Act of 1956 [Електронний ресурс]. - Режим доступа:

https://www.fws.gov/laws/lawsdigest/fwact.html (Дата звернення: 27.08.2019). - Назва 3 екрану.

17. The Fish and Wildlife Coordination Act [Електронний ресурс]. - Режим доступа:

https://www.fws.gov/laws/lawsdigest/FWCOORD.HTML (Дата звернення: 23.08.2019). Назва з екрану.

18. The Lacey Act [Електронний ресурс]. - Режим доступа:

https://www.animallaw.info/article/lacey-act-americas-premier-weapon-fight-against-unlawfulwildlife-trafficking (Дата звернення: 27.08.2019). - Назва з екрану.

19. The Migratory Bird Conservation Act of 1929. URL:

https://www.fws.gov/laws/lawsdigest/migbird.html (Дата звернення 28.08.2019). - Назва 3 екрану.

20. The Migratory Bird Hunting and Conservation Stump [Електронний ресурс]. - Режим доступа: https://www.fws.gov/birds/get-involved/duck-stamp/buy-duck-stamp.php (Дата звернення 27.08.2019). - Назва з екрану.

21. The Migratory Bird Treaty Act [Електронний ресурс]. - Режим доступа:

http:// https://www.audubon.org/news/the-migratory-bird-treaty-act-explained (Дата звернення 28.08.2019). - Назва з екрану.

22. The National Wildlife Refuge System Administration Act of 1966 [Електронний ресурс]. Режим доступа: https://legcounsel.house.gov/Comps/National\%20Wildlife\%20Refuge\%20System\%20Administration\%2 0Act\%20Of\%201966.pdf (Дата звернення 28.08.2019). - Назва з екрану.

23. National Wildlife Refuge System Improvement Act [Електронний ресурс]. - Режим доступа: https://www.fws.gov/refuge/Passage_Key/what_we_do/1997Act.html (Дата звернення 28.08.2019). Назва з екрану.

24. The Wetlands Loan Act [Електронний ресурс]. - Режим доступа:

https://www.fws.gov/laws/lawsdigest/wetloan.html (Дата звернення 28.08.2019). - Назва 3 екрану.

25. The Wild and Scenic Rivers Act [Електронний ресурс]. - Режим доступа: екрану.

https://www.rivers.gov/documents/wsr-act.pdf (Дата звернення 26.08.2019). - Назва 3

26. The Wilderness Act of 1964 [Електронний ресурс]. - Режим доступа:

https://www.wilderness.net/nwps/legisact (Дата звернення 28.08.2019) - Назва з екрану.

27. The Wildlife Restoration Act of 1937 [Електронний ресурс]. - Режим доступа: https://history.house.gov/Historical-Highlights/1901-1950/The-Wildlife-Restoration-Act-of1937/ (Дата звернення 30.08.2019). - Назва з екрану.

\section{References:}

1. Andronov V.A., Varyvoda Y.O., Titenko H.V. (2013). Zapovidna sprava: navch. posib. Xarkiv: NUCZU. 
2. Annual Performance Report FY2015. (2015). U.S. Fish and Wildlife Service. Retrieved from https://www.fws.gov/refuges/about/RefugeReports/pdfs/RAPP_Rpt_2015_final.pdf.

3. Borejko V.E. (2018). Ohrana dikoj prirody v Ukraine i mire. Kiïv: Logos.

4. Brown, R.D. The History of Wildlife Conservation and Research in the United States - and Implications for the Future. (2013). CiteSeers. Retrieved from from http://http://citeseerx.ist.psu.edu/viewdoc/download?doi=10.1.1.494.2051\&rep=rep1\&type=pdf.

5. Curt, D. M.,\& Berry, W. (2010). Aldo Leopold: His Life and Work. Wisconsin: University of Wisconsin Press. Progress.

6. Douglas, D. (1975). Trehsotletnjaja vojna. Hronika jekologicheskogo bedstvija. Moskva:

7. Theodore Roosevelt and Conservation. (2017). National Park Service. Retrieved from http://https://www.nps.gov/thro/learn/historyculture/theodore-roosevelt-and-conservation.htm.

8. Nash, R. F. (2001). Wilderness and the American Mind. New Haven: Yale University Press.

9. Perga, T. (2016). Polityka Teodora Ruzvel"ta u sferi ekolohiyi: konservaciya pryrodnyx resursiv. Problemy vsesvitn"oyi istoriyi 2, 82-96.

10. Parkins, A.E., \& Whitaker J.R. (1946). Our Natural Resources and Their Conservation. New York: John Wiley \& Sons.

11. Pelican Island. (2015). U.S. Fish and Wildlife Service. Retrieved from https://www.fws.gov/refuge/pelican_island/about/history.html/

12. The Alaska National Interest Lands Conservation Act. (2017). National Park Service. Retrieved from_https://www.nps.gov/locations/alaska/anilca.htm.

13. The Animal Disease Control Act. (2001). Congress.gov. Retrieved from

https://www.congress.gov/107/plaws/pub19/PLAW-107pub19.pdf.

14. The Bankhead-Jones Farm Tenant Act of 1937. (2010). Revolvy.com. Retrieved from https://www.revolvy.com/page/Bankhead\%E2\%80\%93Jones-Farm-Tenant-Act-of-1937.

15. The Endangered Species Act of 1973. (2013). U.S. Fish and Wildlife Service. Retrieved from https://www.fws.gov/laws/lawsdigest/esact.html.

16. The Fish and Wildlife Act of 1956. (2013). U.S. Fish and Wildlife Service. Retrieved August 27, 2019, from https://www.fws.gov/laws/lawsdigest/fwact.html.

17. The Fish and Wildlife Coordination Act. (2013). U.S. Fish and Wildlife Service. Retrieved from https://www.fws.gov/laws/lawsdigest/FWCOORD.HTML.1/

18. The Lacey Act (1995). Michigan State University. Retrieved from

$\mathrm{https}$ ///www.animallaw.info/article/lacey-act-americas-premier-weapon-fight-against-unlawfulwildlife-trafficking.

19. The Migratory Bird Conservation Act of 1929. (2013). U.S. Fish and Wildlife Service. Retrieved from https://www.fws.gov/laws/lawsdigest/migbird.html.

20. The Migratory Bird Hunting and Conservation Stump. (2013). U.S. Fish and Wildlife Service. Retrieved from https://www.fws.gov/birds/get-involved/duck-stamp/buy-duck-stamp.php.

21. The Migratory Bird Treaty Act (2018). Audubon. Retrieved from

http:// https://www.audubon.org/news/the-migratory-bird-treaty-act-explained.

22. The National Wildlife Refuge System Administration Act of 1966 (2014). Office of the U.S. Legislative Counsel House of Representatives. Retrieved from https://legcounsel.house.gov/Comps/National\%20Wildlife\%20Refuge\%20System\%20Administration\%2 0Act\%20Of\%201966.pdf.

23. National Wildlife Refuge System Improvement Act. (2013). U.S. Fish and Wildlife Service. Retrieved from https://www.fws.gov/refuge/Passage_Key/what_we_do/1997Act.html.

24. The Wetlands Loan Act. (2013). U.S. Fish and Wildlife Service. Retrieved from https://www.fws.gov/laws/lawsdigest/wetloan.html.

25. The Wild and Scenic Rivers Act (2010). National Wild and Scenic River System. Retrieved from https://www.rivers.gov/documents/wsr-act.pdf.

26. The Wilderness Act of 1964. (2014). Wilderness Connect. Retrieved from https://www.wilderness.net/nwps/legisact.

27. The Wildlife Restoration Act of 1937. (2008). United States House of Representatives. Retrieved from

https://history.house.gov/Historical-Highlights/1901-1950/The-Wildlife-Restoration-Act-of$1937 /$.

Надійшла до редколегії 19.09.2018. 
Перга Тетяна, кандидат історичних наук, старший науковий співробітник, ДУ «Інститут всесвітньої історії НАН України»

\section{ЦІННІСТЬ ДИКОЇ ПРИРОДИ В США: ВІД ІДЕЇ ДО ПРАКТИКИ}

Анотація. Досліджено формування ідеї охорони дикої природи у США. Виявлена роль колонізації північноамериканського континенту у приверненні інтересу до дикої природи, зокрема ї̈ негативний вплив (знищення багатьох видів флори $i$ фауни) $i$ позитивний - відкриття унікальних природних краєвидів. 3 'ясовано внесок американських художників, письменників, науковців $і$ державних діячів XIX - XX cm. у розкриття неекономічної цінності дикої природи і створення перших ділянок з ї охорони. Виявлена роль президента США Теодора Рузвельта у створенні перших природних заповідників США. Зроблено висновок, щзо напередодні Другої світової війни в американському суспільстві вже поширилося розуміння важливості охорони дикої природи, а американськими президентами були здійснені фрагментарні заходи в иій галузі. Саме на иій основі в другій половині ХХ $\mathrm{cm}$. були прийняті перші законодавчі акти щуодо охорони дикої природи, аналіз яких здійснено у статті. Доведено, щзо США першими в світі дали юридичне визначення дикої природи, яке закріплено в Законі 1964 р. "Про дику природу», який власне і став базовим нормативним актом в царині ї̈ охорони. Зроблено висновок, щзо наступним кроком американського уряду із захисту дикої природи стало прийняття законодавства з охорони «диких» річок. Проаналізовано термін «дика» ріка», уведений Законом «Про дикі $і$ мальовничі річки» (1968р.). Розглянуто темпи зростання Національної системи територій дикої природи та порядок створення таких ділянок у США. 3'ясована сутність сучасних проблем охорони дикої природи у США, які пов'язані зі значним збільшенням потреб у ресурсах внаслідок зростання населення та урбанізації, та шляхи їх вирішення. Зроблено висновок про вплив США на розвиток охорони дикої природи у європейських країнах, які прийняли перші закони щодо охорони дикої природи лише у 1990-х роках.

Ключові слова: дика природа, США, екологічна політика, колонізація 